UDC 539.3

\title{
USE OF NUMERICAL HIGH-EXACTLY ALGORITHMS FOR MODELING DYNAMIC DEMEANOUR OF DISRETELY SUBSTANTIATED FIVE-LAYERED CYLINDRICAL SHELLS
}

N. V. ARNAUTA, Candidate of Physics and Mathematics Sciences,

R. R. ROMAN, student

National university of live and environmental sciences of Ukraine

E-mail: arnauta_alex@ukr.net

https: / /doi.org/10.31548/bio2018.05.027

The purpose of this scientific-essay is constructionation numerical dynamical task solving algorithm of multilayered discretely substantiated shells, that based on using Richardson finite-difference approximations types. Multilayered discretely substantiated shells refer to complex nonuniformity by thickness elasticity-structures. In one reason, nonuniformity existed because of shell-flakiness structure, in other case - because of existing discretely substantiated edges. Including the discretely count of substantiated elements brings to exist new bursting coefficients on spatial coordinates in output equations. Numerical method usage (finite-difference method, finite-elements method etc.) for solving dynamic-progressions tasks in listed structures observing convergence of the worsening numerical results. For the constructing more effective numerical algorithms used the method, which based on finding approximation solutions by Richardson.

Ключові слова: multilayered shells, discrete nonuniformities, finite-difference approximations

Multilayered discretely substantiated shells refer to complex nonuniformity by thickness elasticity-structures. In one reason, nonuniformity existed because of shellflakiness structure, in other case - because of existing discretely substantiated edges. Including the discretely count of substantiated elements brings to exist new bursting coefficients on spatial coordinates in output equations [1, 2]. Numerical method usage (finite-difference method, finite-elements method etc.) for solving dynamic-progressions tasks in listed structures observing convergence of the worsening numerical results. For the constructing more effective numerical algorithms used the method, which based on finding approximation solutions by Richardson [3-5].

In this work we are investigating: nonstationary progression of multilayered discretely substantiated cylindrical shells, the construction of numerical algorithm in case of Richardson approximations types use and the solutions of tasks with the analyzing their results.

Nonuniformity elastic structure is multilayered smooth cylindrical shell with hardly connected layers and discretely substantiated circled elements. It means that 
the elastic structure count of stresseddistorted status (SDS) is using geometric nonlinear kernel theory and the Tymoshenko type shells. Antisymmetric equation vacillation modes of multilayered nonuniformity elastic structure are the partial cases of next equations [2]:

1) equation vacillation modes of multilayered shell in the smooth area between comparable discrete edges

$$
\begin{aligned}
& \frac{\partial \mathrm{T}_{11}}{\partial \mathrm{x}}+\mathrm{P}_{1}=\mathrm{I}_{1} \frac{\partial^{2} \mathrm{U}_{1}}{\partial \mathrm{t}^{2}}+\mathrm{I}_{2} \frac{\partial^{2} \varphi_{1}}{\partial \mathrm{t}^{2}}, \\
& \frac{\partial \overline{\mathrm{T}}_{13}}{\partial \mathrm{x}}+\frac{\mathrm{T}_{22}}{\mathrm{R}}+\mathrm{P}_{3}=\mathrm{I}_{1} \frac{\partial^{2} \mathrm{U}_{3}}{\partial \mathrm{t}^{2}}, \\
& \frac{\partial \mathrm{M}_{11}^{*}}{\partial \mathrm{x}}-\mathrm{T}_{13}+\mathrm{m}_{1}=\mathrm{I}_{2} \frac{\partial^{2} \mathrm{U}_{1}}{\partial \mathrm{t}^{2}}+\mathrm{I}_{3} \frac{\partial^{2} \varphi_{1}}{\partial \mathrm{t}^{2}} \\
& \overline{\mathrm{T}}_{13}=\mathrm{T}_{13}+\mathrm{T}_{11} \Theta_{1}, \mathrm{M}_{11}^{*}=\mathrm{M}_{11} \pm \mathrm{h}_{\mathrm{cm}} \mathrm{T}_{11}
\end{aligned}
$$

2) equation vacillation mode $j$-ing ending kernel in gap points $\mathrm{X}=\mathrm{x}_{\mathrm{j}}$ (The mass centre projected points of the cross-section on the middle segment in the smooth multilayered shell)

$$
\begin{gathered}
{\left[\mathrm{T}_{11}\right]_{\mathrm{j}}=\rho_{\mathrm{j}} \mathrm{F}_{\mathrm{j}}\left(\frac{\partial^{2} \mathrm{u}_{1}}{\partial \mathrm{t}^{2}} \pm \mathrm{h}_{\mathrm{cj}} \frac{\partial^{2} \varphi_{1}}{\partial \mathrm{t}^{2}}\right),} \\
{\left[\overline{\mathrm{T}}_{13}\right]_{\mathrm{j}}-\frac{\mathrm{T}_{22 \mathrm{j}}}{\mathrm{R}_{\mathrm{j}}}=\rho_{\mathrm{j}} \mathrm{F}_{\mathrm{j}} \frac{\partial^{2} \mathrm{u}_{3}}{\partial \mathrm{t}^{2}},} \\
{\left[\mathrm{M}_{11}\right]_{\mathrm{j}}=\rho_{\mathrm{j}} \mathrm{F}_{\mathrm{j}}\left[ \pm \mathrm{h}_{\mathrm{j}}\left(\frac{\partial^{2} \mathrm{u}_{1}}{\partial \mathrm{t}^{2}} \pm \mathrm{h}_{\mathrm{cj}} \frac{\partial^{2} \varphi_{1}}{\partial \mathrm{t}^{2}}\right)+\frac{\mathrm{I}_{\mathrm{kpj}}}{\mathrm{F}_{\mathrm{i}}} \frac{\partial^{2} \varphi_{1}}{\partial \mathrm{t}^{2}}\right],} \\
\text { where } \\
\left(\mathrm{T}_{11}, \mathrm{~T}_{22}, \mathrm{~T}_{13}\right)=\sum_{\mathrm{k}} \int_{\mathrm{z}}\left(\sigma_{11}^{\mathrm{kz}}, \sigma_{22}^{\mathrm{kz}}, \sigma_{13}^{\mathrm{kz}}\right) \mathrm{dz}, \\
\left(\mathrm{M}_{11}\right)=\sum_{\mathrm{k}} \int_{\mathrm{z}}\left(\mathrm{z} \sigma_{11}^{\mathrm{kz}}\right) \mathrm{dz}, \\
\mathrm{I}_{1}=\sum_{\mathrm{k}} \rho_{\mathrm{k}} \mathrm{h}_{\mathrm{k}}, \quad \mathrm{I}_{2}=\sum_{\mathrm{k}} \pm \rho_{\mathrm{k}} \mathrm{h}_{\mathrm{k}} \mathrm{h}_{\mathrm{ck}}, \\
\mathrm{I}_{3}=\sum_{\mathrm{k}} \rho_{\mathrm{k}} \frac{\mathrm{h}_{\mathrm{k}}}{12} .
\end{gathered}
$$

In the equations (1) - (2) have been inputted next variables: $\mathbf{X}, \mathbf{t}-$ area and time coordinates, $\mathrm{R}$ - radius of the exampled middle multilayered surface shell; $\rho_{\mathrm{k}}, \quad \rho_{\mathrm{j}}-$ materials density of $\mathrm{k}$ - ing layer shell and $\mathrm{j}$-ing edge; $\mathrm{h}_{\mathrm{k}}$ - the layers shell thicknesses, $\mathbf{h}_{\mathbf{c k}}$ - the length from output middle area to the middle area of $\mathbf{K}$ - ing layer; $\mathbf{h}_{\mathbf{c j}}$ - the length from output middle area to the centre line of the cross-section mass $\mathrm{j}$-ing edge; $\mathrm{x}_{\mathrm{j}}$ - coordinate of contact line $\mathrm{j}$-ing edge with multilayer shell; $\mathrm{R}_{\mathrm{j} .}, \mathrm{F}_{\mathrm{j}}, \mathrm{I}_{\mathrm{kpj}}$ - geometric parameters of $\mathbf{j}$ - ing edge. In the markers for indexes of efforts and moments considered, that $\sigma_{11}^{\mathrm{kz}}, \sigma_{22}^{\mathrm{kz}}, \sigma_{13}^{\mathrm{kz}}$ - stresses in thickness $\mathrm{k}=\overline{1, \mathrm{n}}$.

The catena between pointmence of stress and deformation components gets from formulas:

$$
\begin{gathered}
\sigma_{11}^{\mathrm{kz}}=\frac{\mathrm{E}_{1}^{\mathrm{k}}}{1-v_{1}^{\mathrm{k}} v_{2}^{\mathrm{k}}}\left(\varepsilon_{11}^{\mathrm{kz}}+v_{2}^{\mathrm{k}} \varepsilon_{22}^{\mathrm{kz}}\right), \\
\sigma_{22}^{\mathrm{kz}}=\frac{\mathrm{E}_{2}^{\mathrm{k}}}{1-v_{1}^{\mathrm{k}} v_{2}^{\mathrm{k}}}\left(\varepsilon_{22}^{\mathrm{kz}}+v_{1}^{\mathrm{k}} \varepsilon_{11}^{\mathrm{kz}}\right), \\
\sigma_{13}^{\mathrm{kz}}=\mathrm{G}_{13}^{\mathrm{kz}} \varepsilon_{13}^{\mathrm{kz}},
\end{gathered}
$$

where tensor deformation components in the coordinate systems $\mathbf{X}, \mathrm{Z}$ seens like:

$$
\begin{gathered}
\varepsilon_{11}^{\mathrm{kz}}=\varepsilon_{11}^{\mathrm{k}}+\mathrm{z} \vartheta_{11}^{\mathrm{k}}, \quad \varepsilon_{22}^{\mathrm{kz}}=\kappa_{2} \mathrm{u}_{3}^{\mathrm{k}}, \varepsilon_{13}^{\mathrm{kz}}=\varphi_{1}^{\mathrm{k}}+\theta_{1}^{\mathrm{k}}, \\
\varepsilon_{11}^{\mathrm{k}}=\frac{\partial \mathrm{u}_{1}^{\mathrm{k}}}{\partial \mathrm{x}}+\frac{1}{2}\left[\theta_{1}^{\mathrm{k}}\right]^{2}+\kappa_{1} \mathrm{u}_{3}^{\mathrm{k}}, \vartheta_{11}^{\mathrm{k}}=\frac{\partial \varphi_{1}^{\mathrm{k}}}{\partial \mathrm{x}}, \\
\theta_{1}^{\mathrm{k}}=\frac{\partial \mathrm{u}_{3}^{\mathrm{k}}}{\partial \mathrm{x}}-\kappa_{1} \mathrm{u}_{1}^{\mathrm{k}}, \mathrm{k}=\overline{1, \mathrm{n}} .
\end{gathered}
$$

Equation vacillation mode (1) - (4) added by natural limiting and initial conditions.

One of the main limiting-task solvingproblems in substantiated with calculated edges space discrete shells are existence of bursting coefficients in vacillation mode 
equations. In case of $[1,2]$, we are searching the solve on the smooth part and we are linking on the bursting lines. In this task, bursting lines are centre mass cross-section projecting points of j-ing edge in the middle of sheathing area.

For the constructing equation solvation difference-schemes (1) - (4) used integrational-interpolated method of constructing finite-difference scheme [3] for hyperbole equation. In this case, equation (1) interpreted in area like $\left\{\mathrm{x}_{1-1 / 2} \leq \mathrm{x} \leq \mathrm{x}_{1+1 / 2}, \mathrm{t}_{\mathrm{n}-1 / 2} \leq \mathrm{t} \leq \mathrm{t}_{\mathrm{n}+1 / 2}\right\}$

$$
\int_{t_{n-1 / 2}}^{t_{n+1 / 2}} \int_{x_{1-1 / 2}}^{x_{1+1 / 2}} \frac{\partial T_{11}}{\partial x} d x d t=\int_{t_{n-1 / 2}}^{t_{n+1 / 2}} \int_{x_{1-1 / 2}}^{x_{1+1 / 2}}\left[I_{1} \frac{\partial^{2} u_{1}}{\partial t^{2}}+I_{2} \frac{\partial^{2} \varphi_{1}}{\partial t^{2}}\right] d x d t
$$

$\int_{t_{n-1 / 2}}^{t_{n+1 / 2}} \int_{x_{1-1 / 2}}^{x_{1+1 / 2}}\left[\frac{\partial \bar{T}_{13}}{\partial x}-\frac{\partial T_{22}}{R}+P_{3}(x, t)\right] d x d t=\int_{t_{n-1 / 2}}^{t_{n+1 / 2}} \int_{1-1 / 2}^{x_{1+1 / 2}} I_{1} \frac{\partial^{2} u_{3}}{\partial t^{2}} d x d t ;$

$\int_{t_{n-1 / 2}}^{t_{n+1 / 2}} \int_{x_{1-1 / 2}}^{x_{1+1 / 2}}\left[\frac{\partial M_{11}^{*}}{\partial x}-T_{13}\right] d x d t=\int_{t_{n-1 / 2}}^{t_{n+1 / 2}} \int_{x_{1-1 / 2}}^{x_{1+1 / 2}}\left[I_{2} \frac{\partial^{2} u_{1}}{\partial t^{2}}+I_{3} \frac{\partial^{2} \varphi_{1}}{\partial t^{2}}\right] d x d t$.

After standard interpretations in correlations (5), we are getting these difference approximations of the equations (1)

$$
\begin{aligned}
& \mathrm{L}_{1}\left(\overline{\mathrm{U}}_{1}^{\mathrm{n}}\right)=\mathrm{I}_{1}\left(\mathrm{u}_{11}^{\mathrm{n}}\right)_{\overline{\mathrm{t}} \mathrm{t}}+\mathrm{I}_{2}\left(\varphi_{11}^{\mathrm{n}}\right)_{\overline{\mathrm{t}} \mathrm{t}} ; \\
& \mathrm{L}_{2}\left(\overline{\mathrm{U}}_{1}^{\mathrm{n}}\right)+\mathrm{P}_{3}\left(\mathrm{x}_{1}, \mathrm{t}_{\mathrm{n}}\right)=\mathrm{I}_{1}\left(\mathrm{u}_{31}^{\mathrm{n}}\right)_{\overline{\mathrm{t}} \mathrm{t}} ; \\
& \mathrm{L}_{3}\left(\overline{\mathrm{U}}_{1}^{\mathrm{n}}\right)=\mathrm{I}_{2}\left(\mathrm{u}_{11}^{\mathrm{n}}\right)_{\overline{\mathrm{t}} \mathrm{t}}+\mathrm{I}_{3}\left(\varphi_{11}^{\mathrm{n}}\right)_{\overline{\mathrm{t}} \mathrm{t}} ;
\end{aligned}
$$

where

$$
\mathrm{L}_{1}\left(\overline{\mathrm{U}}_{1}^{\mathrm{n}}\right)=\frac{\mathrm{T}_{111+1 / 2}^{\mathrm{n}}-\mathrm{T}_{111-1 / 2}^{\mathrm{n}}}{\Delta \mathrm{x}} ;
$$

$\mathrm{L}_{2}\left(\overline{\mathrm{U}}_{1}^{\mathrm{n}}\right)=\frac{\overline{\mathrm{T}}_{131+1 / 2}^{\mathrm{n}}-\overline{\mathrm{T}}_{131-1 / 2}^{\mathrm{n}}}{\Delta \mathrm{x}}-\frac{\mathrm{T}_{221+1 / 2}^{\mathrm{n}}+\mathrm{T}_{221-1 / 2}^{\mathrm{n}}}{2 \mathrm{R}} ;$

$\mathrm{L}_{3}\left(\overline{\mathrm{U}}_{1}^{\mathrm{n}}\right)=\frac{\mathrm{M}_{111+1 / 2}^{* \mathrm{n}}-\mathrm{M}_{111-1 / 2}^{* \mathrm{n}}}{\Delta \mathrm{x}}-\frac{\mathrm{T}_{131+1 / 2}^{\mathrm{n}}+\mathrm{T}_{131-1 / 2}^{\mathrm{n}}}{2}$.
In correlations (6) $\overline{\mathrm{U}}_{1}^{\mathrm{n}}=\left(\mathrm{u}_{11}^{\mathrm{n}}, \mathrm{u}_{31}^{\mathrm{n}}, \varphi_{11}^{\mathrm{n}}\right)$, the discrete derivative variable puts like [6]. Like seen in item (6), variable of efforts and moments correlates to difference points in the half-integer points at the space coordinate and in integer points at the time coordinate.

$$
\left(\mathrm{T}_{1}, \mathrm{~T}_{2}, \overline{\mathrm{T}}_{\mathrm{B}}, \mathrm{M}_{1}\right) \rightarrow
$$

$\left(\mathrm{T}_{11 \pm 1 / 2}^{\mathrm{n}}, \mathrm{T}_{2}^{\mathrm{n}} 1 \pm 1 / 2, \overline{\mathrm{T}}_{1 \pm 1 / 2}^{\mathrm{n}}, \mathrm{M}_{11 \pm 1 / 2}^{\mathrm{n}}\right)$

In the equations (3) - (4) areas are integrate

$$
\begin{aligned}
& \left\{\mathrm{x}_{1-1} \leq \mathrm{x} \leq \mathrm{x}_{1}, \mathrm{t}_{\mathrm{n}-1 / 2} \leq \mathrm{t} \leq \mathrm{t}_{\mathrm{n}+1 / 2}\right\} \\
& \left\{\mathrm{x}_{1} \leq \mathrm{x} \leq \mathrm{x}_{1+1}, \mathrm{t}_{\mathrm{n}-1 / 2} \leq \mathrm{t} \leq \mathrm{t}_{\mathrm{n}+1 / 2}\right\}
\end{aligned}
$$

Similarly, happens the numerical integrate of equation vacillation mode (2) for $\mathrm{j}$ - ing substantiated element.

Like we seen, in some case, when we solve numerical equations (1) - (4) by the approximation basis (6) creates the deterioration of convergences numerical results. For the constructing more effective algorithms, we are using the method, which is based on finding Richardsonapproximation results [7].Although, when the difference step is fixed on the time coordinate, we are using the progression of approximations on the space coordinate. Herewith the extrapolation procedure forms like

$$
\begin{aligned}
& {\widetilde{\mathrm{U}_{1}}}_{1(\Delta \mathrm{x})}^{\mathrm{n}}=\frac{4}{3} \overline{\mathrm{U}}_{1(\Delta \mathrm{x} / 2)}^{\mathrm{n}}-\frac{1}{3} \overline{\mathrm{U}}_{1(\Delta \mathrm{x})}^{\mathrm{n}} \text {, } \\
& \text { where } \quad \overline{\mathrm{U}}_{1(\Delta \mathrm{x})}^{\mathrm{n}} \quad \text { i } \quad \overline{\mathrm{U}}_{1(\Delta \mathrm{x} / 2)}^{\mathrm{n}}
\end{aligned}
$$

numerical results of equations vacillation modes (6), (7) similar with discrete steps on space coordinate $\Delta \mathrm{x}$ i $\Delta \mathrm{x} / 2$.

The difference equations (8) approximate the output of equation vacillation mode (1) in smooth area with forth accuracy order at the coordinate $\mathrm{X}$.

Like the numerical example, we have solved the task which consist determination of the stressed-deformed state of a five-layer cylindrical shell at a non-stationary load [5]. 


\section{Calculations for the $U_{3}$ variable}

\begin{tabular}{|c|c|c|c|c|c|}
\hline \multicolumn{3}{|c|}{ Standard calculations } & \multicolumn{3}{c|}{ Richardson's method calculations } \\
\hline$\Delta \mathrm{t}$ & 1 & $\mathrm{U}_{3} \cdot 10^{-4}, \mathrm{M}$ & $\Delta \mathrm{t}$ & 1 & $\mathrm{U}_{3} \cdot 10^{-4}, \mathrm{M}$ \\
\hline$\Delta \mathrm{t}_{1}$ & 40 & 0,557 & $\Delta_{1}$ & $40 \div 80$ & 0,573 \\
\hline & 80 & 0,569 & & \multirow{2}{*}{$80 \div 160$} & 0,574 \\
\hline $0,5 \cdot \Delta \mathrm{t}_{1}$ & 160 & 0,573 & & & \\
\hline
\end{tabular}

2. Calculations for the $U_{3}$ variable (on the bursting line)

\begin{tabular}{|l|c|c|c|c|c|}
\hline \multicolumn{3}{|c|}{ Standard calculations } & \multicolumn{3}{c|}{ Richardson's method calculations } \\
\cline { 1 - 3 }$\Delta \mathrm{t}$ & 1 & $\mathrm{U}_{3} \cdot 10^{-4}, \mathrm{M}$ & $\Delta \mathrm{t}$ & 1 & $\mathrm{U}_{3} \cdot 10^{-4}, \mathrm{M}$ \\
\hline$\Delta \mathrm{t}_{1}$ & 40 & 0,275 & $\Delta \mathrm{t}_{1}$ & $40 \div 80$ & 0,292 \\
\hline & 80 & 0,288 & & & 0,293 \\
\hline & 160 & 0,292 & & & \\
\cline { 1 - 3 } & 320 & 0,292 & & & \\
\hline
\end{tabular}

The limited goal for this task must be like $\mathrm{x}=0, \mathrm{x}=\mathrm{L}: \mathrm{U}_{1}=\mathrm{U}_{2}=\varphi_{3}=0$; where $\mathrm{L}-$ length of shell. The begging goal phase is null.

Non-stationery defined load input like:

$$
\mathrm{P}_{3}(\mathrm{t})=\mathrm{A} \sin \left(\frac{\pi \mathrm{t}}{\mathrm{T}}\right)[\eta(\mathrm{t})-\eta(\mathrm{t}-\mathrm{T})]
$$

where $\mathrm{A}$ - load amplitude, $\mathrm{T}$ - time of load. Geometric and phys-math parameter have taken from [2-4].

In 1 table we could see the partly results of two method - standart method by formulas (6), (7) with fixed step $\Delta \mathrm{x}$ and like a Richardson method with steps $\Delta \mathrm{x}$ i $\Delta \mathrm{x} / 2$. In $1-2$ tables we could see the results about the smooth area shell for the variable $\mathrm{U}_{3} \mathrm{i}$ in the profile of the shell $x=7 \mathrm{~L} / 40$ for fixed time $t=8,5 \mathrm{~T} \quad(1$ - count of discrete intervals by the space coordinate). In 2 table we have used the analogical methods on the bursting space line $\mathrm{x}=0,1 \mathrm{~L}$, (it is the edge mass centre position of cross-section on the given middle typed surface) when $\mathrm{t}=8,5 \mathrm{~T}$.

The Richardson extrapolation method helps us to achieve better accuracy on the coarser difference grids in space coordinates then it could be in the standard numerical equation solution. This method usage optimized the process in operational count in three times $(\approx 1,5$ times because of space grid usage and 2 times because of discrete time step).

\section{References}

1. Lugova P. Z., Meysh V. F., Meish Y. A. (2014). Solving the problems of dynamic behavior of reinforced cylindrical shells (constructive orthotropic model) with non-stationary charges. Problems of computational mechanics and structural strength: a collection of scientific works, 23:115-123.

2. Meysh V. F, Arnauta N. V. (2010). Numerical algorithm for calculating axisymmetric oscillations of three-layer reinforced cylindrical shells using finite-difference Richardson approximants. Problems of computational mechanics and structural strength. Book of scientific works (Dnipropetrovsk National University named after Oles Honchar),14:246-253. 
3. Meysh V. F, Arnauta N. V. (2011). To calculate axisymmetric oscillations of five-layer reinforced cylindrical shells with longitudinal boundary load. Problems of computational mechanics and structural strength. Collection of scientific works (Dnipropetrovsk National University named after Oles Honchar), 15:107-113.

4. Meysh V. F., Kravchenko N. V. (2002). The calculation of outwardly-deformed state of multilayer shells with discrete inhomogeneities in non-stationary loads. Bulletin of the University of Kiev. Series: phys. Mat. science, 3:210-216.

5. Meysh V. F, Arnauta N. V. (2013). Using the Richardson approximation for numerical simulation of dynamic behavior of multilayer discretely reinforced cylindrical shells under non-stationary loads. Book of scientific works of Dneprodzerzhinsky State Technical University (technical sciences), 2(22):128-133.

6. Samarsky A. A. (1977). Theory of difference schemes. 656.

7. Marchuk G. I. (1977). Methods of computational mathematics. 454.

\section{АНОТАЦІЯ}

Н. В. Арнаута, Р. Р. Роман. Застосування чисельних алгоритмів підвищеної точності для моделювання динамічної поведінки дискретно підкріплених п'ятишарових ииліндричних оболонок. Біоресурси і природокористування. 2018. 10, № 5-6. C. 217-222. https:// doi.org/10.31548/bio2018.05.027

Метою даного повідомлення $\epsilon$ побудова иисельного алгоритму розв'язування динамічних задач теорії багатошарових дискретно підкріплених оболонок, який базується на застосуванні скінчено - різнищевих апроксимаиій типу Річардсона.

Багатошарові дискретно підкріплені оболонки представляють собою складні неоднорідні по товиині пружні структури. 3 однієї сторони неоднорідність обумовлена шаруватістю оболонкової структури, з іншой - наявністю дискретних підкріплюючих ребер. Врахування дискретності підкріплюючих елементів приводить до появи розривних коефічієнтів по просторовій координаті в вихідних рівняннях. При застосуванні чисельних методів (метод скінчених різниць, метод скінчених елементів $i$ тощо) для розв'язування задач динамічної поведінки вказаних структур спостерігається погіршення збіжності чисельних результатів. Для побудови більш ефективних чисельних алгоритмів застосовується підхід, шо базується на знаходженні наближених розв'язків по Річардсону.

Ключові слова: багатошарові оболонки, дискретні неоднорідності, скінчено - різничевих апроксимахій

\section{АННОТАЦИЯ}

Н. В. Арнаута, Р. Р. Роман. Использование численных алгоритмов повышенной точноти для моделирования динамического поведения дискретно подкрепленных пятислойных оболочек. Биоресурсы и природопользование. 2018. 10, №5-6. C. 217-222. https://doi.org/10.31548/ bio2018.05.027

Цель данного сообщения - построение численного алгоритма решения динамических задаи теории многослойных дискретно подкрепленных оболочек, основанного на использовании конечно-разностных аппроксимачий типу Ричардсона.

Многослойные дискретно подкрепленные оболочки представляют собою сложные неоднородные по толшине упругие структуры. С одной сторонъ неоднородность обусловлена слочстостью структуры оболочки, с другой - наличием дискретных подкрепляюших ребер. Уиет дискретности подкрепляюших элементов приводить к полвлению разрывных коэффиииентов по пространственной координате в выходных уравнениях. При использовании численных методов для решения задач динамического поведения указанных структур наблюдается ухудшение сходимости. иисленных результатов. Для построения более аффективных численных алгоритлов используется подход, основанный на нахождении приближенньх решений по Ричардсону.

Ключевые слова: многослойные оболочки, дискретнье оболочки, конечно-разносные аппроксимачии 